IZA DP No. 8072

The Impact of Adolescent Motherhood on Education in Chile

Matias Berthelon

Diana I. Kruger

March 2014 


\title{
The Impact of Adolescent Motherhood on Education in Chile
}

\author{
Matias Berthelon \\ Universidad Adolfo Ibañez \\ Diana I. Kruger \\ Universidad Adolfo Ibañez \\ and IZA
}

\section{Discussion Paper No. 8072 \\ March 2014}

\author{
IZA \\ P.O. Box 7240 \\ 53072 Bonn \\ Germany \\ Phone: +49-228-3894-0 \\ Fax: +49-228-3894-180 \\ E-mail: iza@iza.org
}

Any opinions expressed here are those of the author(s) and not those of IZA. Research published in this series may include views on policy, but the institute itself takes no institutional policy positions. The IZA research network is committed to the IZA Guiding Principles of Research Integrity.

The Institute for the Study of Labor (IZA) in Bonn is a local and virtual international research center and a place of communication between science, politics and business. IZA is an independent nonprofit organization supported by Deutsche Post Foundation. The center is associated with the University of Bonn and offers a stimulating research environment through its international network, workshops and conferences, data service, project support, research visits and doctoral program. IZA engages in (i) original and internationally competitive research in all fields of labor economics, (ii) development of policy concepts, and (iii) dissemination of research results and concepts to the interested public.

IZA Discussion Papers often represent preliminary work and are circulated to encourage discussion. Citation of such a paper should account for its provisional character. A revised version may be available directly from the author. 


\section{ABSTRACT}

\section{The Impact of Adolescent Motherhood on Education in Chile ${ }^{*}$}

We analyze the effect of having a child in adolescence on high school completion, educational attainment, and college enrollment in a developing country setting using nine repeated rounds of Chilean household surveys that span the 1990-2009 period. We control for selection bias and household unobservables of teen motherhood with two approaches: different estimation methods - propensity score matching and family fixed effects for a large sub-sample of sisters - and three different samples. Results reveal that adolescent motherhood reduces the probability of high school completion by between 18 to 37 percent. Furthermore, effects are heterogeneous across education groups: teen motherhood has larger negative effects on high school completion and years of schooling among poor and low-education households. Our results imply that policies aimed at reducing early childbearing will have important short-term effects on young women's education outcomes.

JEL Classification: $\quad$ O15, J13, 125

Keywords: education, teen pregnancy, adolescent motherhood, youth, high school, Chile

Corresponding author:

Diana Kruger

Adolfo Ibañez Business School

Avenida Padre Hurtado 750

Viña del Mar

Chile

E-mail: diana.kruger@uai.cl

\footnotetext{
* The authors received financial support from Chile's Comisión Nacional de Investigación Científica y Tecnológica (CONICYT), through FONDECYT Projects No.1070447 and 1120882 . The authors would like to thank Melanie Oyarzun for diligent research assistance, as well comments received from seminar participants at the Universidad de Chile, Universidad Católica de Chile, and Universidad Alberto Hurtado. All errors and omissions are our own.
} 


\section{Introduction}

The relationship between adolescent motherhood and a woman's future human capital (HC) outcomes has been analyzed by sociologists and economists for decades, mostly in the United States and Great Britain. ${ }^{1}$ Early studies analyzing the effects of teenage childbearing found that it has negative impacts on women's outcomes such as educational attainment, various labor market outcomes, incidence of poverty, single motherhood, and dependence on state welfare programs.

However, some of the results of the early findings were challenged on methodological grounds as it has been widely documented that teens who become mothers are different than those who delay childbirth in both observable and unobservable characteristics, so that the differences in their adult economic outcomes are not necessarily due to the young age of their first birth but to unmeasured variables. ${ }^{2}$ Some identification strategies that have been implemented to address this problem include comparison of sisters' outcomes (Geronimus and Korenman, 1992, 1993; Hoffman et al. 1993); comparing outcomes of teens who gave birth to twins vs. singleton births (Grogger and Bronars, 1993), quasi natural experiments such as miscarriages (Hotz, McElroy and Sanders, 2005; Ashcraft, Fernández and Lang, 2013; Fletcher and Wolfe, 2009), and propensity score matching based on observables (Levine and Painter, 2003; Lee, 2010). Most studies that applied the identification strategies mentioned above found that OLS estimates that do not account for selection had over-stated the effects of teenage childbearing on human capital outcomes; however, even after accounting for the selection bias

\footnotetext{
${ }^{1}$ Most of the literature has focused on U.S. data due to data availability, and to the fact that, among high-income OECD countries, it is one with the highest rate of teen pregnancy: 54 per 1,000 women aged 15-19 years, followed by Great Britain, with 28 births per 1,000 adolescent women (Muñoz, 2005.)

${ }^{2}$ For a clear summary of the methodological issues, see Hoffman 1998.
} 
the effects of motherhood are not zero. ${ }^{3}$ And although the methodological debate is far from over, findings in the literature confirm that giving birth as an adolescent has negative effects on high school completion, years of schooling, and income and that it increases the likelihood of participating in public poverty assistance programs (Fletcher and Wolfe, 2009).

Studies that estimate the effects of early childbearing on women's schooling and future socio-economic outcomes in Latin American countries are scarce, despite the fact that it is an issue of serious public policy concern. ${ }^{4}$ In an international survey of 43 developing countries during the 1990s, Singh (1998) finds that despite increasing coverage of secondary education in Latin America, the decline in adolescent motherhood has been small, with some countries experiencing increases in teenage childbearing.

This paper aims to contribute to the literature by estimating the effects of adolescent childbearing on young women's education outcomes in a developing country setting. Chile has gained international recognition for important reductions in poverty since 1990, and for large increases in education coverage. Nonetheless, high school desertion rates remain high among older teens and among lower-income youths, with almost one third of teens aged 18-19 years not attending high school..$^{5}$ At the same time data from household surveys shows that 31 percent of high school-aged girls (15 to 18 years) cited maternity as the most important reason for not attending high school in 2009.

Estimating the effect of an adolescent birth on the young mother's future outcomes is difficult to establish. Human capital theory predicts that a teenage birth interferes with the mother's education, because it increases the opportunity cost of obtaining an education. Furthermore, due to time constraints, child rearing activities interfere with time required by

\footnotetext{
${ }^{3}$ Exceptions are Hotz et al. (2005) and Azevedo et al. (2012), which find slightly better adult outcomes among women who became mothers as teens relative to those that miscarried. However, en earlier version of Hotz et al. (2005) was challenged due to small sample size (Hoffman, 1998).

${ }^{4}$ Exceptions are Buvinic (1998) and Azevedo et al. (2012).

${ }^{5}$ MIDEPLAN, 2003.
} 
education activities, so that having a child as a teen would reduce human capital accumulation. Early studies estimated the effect of a teen birth on the mother's human capital outcomes empirically by estimating OLS (or limited dependent variable) regressions of the variable of interest on a set of explanatory variables, one of which was whether the woman gave birth as a teen. However, as many researchers — sociologists and economists alike-began to point out since the early 1990s, the estimated coefficient in such estimations does not consider selfselection into motherhood. A teen birth is not a random event: young women who become mothers in adolescence are different, in terms of observable characteristics, from those that do not - they are usually from poorer and more disadvantaged households and neighborhoods. Thus, it is probable that girls who became mothers as teens would have had a different education and labor market trajectory relative to girls who delay motherhood into adulthood, even if they had not become mothers.

Additionally, adolescents who become mothers are probably different in terms of unobservable characteristics as well. For example, fertility and educational decisions may both be determined by a girl's ability in school, which is not usually observed: girls with lower academic skills are likely to face more challenges in school than girls with higher ability and are more likely to drop out, thus, they face lower costs of becoming mothers during their teenage years (Levine and Painter, 2003). ${ }^{6}$

Recent studies on the effects of teen pregnancy address both observable and nonobservable selection through various methodologies. One approach is to control for unmeasured environmental factors by controlling for within-family fixed effects (Geronimus and Korenman, 1992 and 1993; Hoffman et al., 1993; Rosenzweig and Wolpin, 1995). These studies compare outcomes of sisters who timed their births at different stages-i.e., they compare sisters who

\footnotetext{
${ }^{6}$ In Chile, almost $10 \%$ of girls who drop out of high school say they did so because they are not interested in attending high school, and $4.1 \%$ do not attend because of academic difficulties (see Table 1).
} 
were adolescent mothers with those that were not. The studies find that cross-sectional estimates from OLS-type regressions overestimate the effect of a teen birth, and depending on the data used, the effect disappears altogether.

Another methodological approach that controls for selection is instrumental variables, where estimations measure the impact of the exogenous variation in teen motherhood on the outcomes of interest. The practical challenge is to find data on variables that affect teenage motherhood and not the socioeconomic outcome under study. Instruments that have been analyzed in previous research are age at menarche and access to abortion (in the U.S. and Great Britain), which are likely correlated to a teen birth but not to education outcomes of young women. The findings of these studies are mixed-some find no effects of a teen birth on mothers' future outcomes (Ribar, 1994; Olsen and Farkas, 1989) while others find that the negative effect subsists even after taking the endogeneity into account (Klepinger et al., 1999).

Other researchers have constructed artificial control groups for teenage mothers through propensity score matching (Levine and Painter, 2003; Chevalier and Viitanen, 2003), where women who were teenage mothers are considered the "treated" group and a "control" group of women with similar observed characteristics is constructed. Lee (2010) goes one step further and analyzes the extent of the selection bias due to unobservable characteristics. These studies find that giving birth as a teen reduces future education outcomes of mothers, and Lee (2010) additionally finds that the selection bias based on unobservables would have to be stronger than the effects of observable covariates to nullify the effect of a teen pregnancy on high school completion and college enrollment.

A final methodological approach that has been applied in the literature is to take advantage of quasi-natural experiments. An early study was Grogger and Bronars (1993), which compared the effects of a twin birth relative to singleton births to adolescent mothers. The study 
found that women who had twins as adolescents had lower education and socio-economic outcomes than those who gave birth to one child in adolescence, but the effects are modest and are present only among blacks in the U.S. The innovative premise of their study is that by analyzing only adolescent mothers, selection into motherhood is no longer a methodological issue, and that the (mostly) random incidence of twins identifies the effects of teenage motherhood.

Hotz, McElroy and Sanders (2005) follow a similar quasi-experimental approach and compare outcomes of women who became pregnant as teenagers and gave birth, with those of women who became pregnant and had miscarriages. ${ }^{7}$ The idea is that miscarriages are random events, and all the women analyzed became pregnant as teenagers so they are probably similar in terms unobservables. Ashcraft, Fernández and Lang (2013) and Fletcher and Wolfe (2009) take into account the possibility that women have an induced abortion before they miscarry, and they adjust the estimates through various assumptions of the timing of abortions and miscarriages. In these latter studies, the authors find that after controlling for observable and unobservable selection bias and accounting for the timing of a miscarriage vis-à-vis an abortion, a teenage birth reduces the mother's high school completion and years of schooling.

Attempts to estimate the causal effect of a teen birth on mothers' future socioeconomic outcomes are in an early stage in less developed countries. Following a similar approach as Hotz et al., Azevedo et al. (2012) estimate the effect of adolescent motherhood on mothers' socioeconomic outcomes in Mexico by comparing women who gave birth as teens with women who became pregnant but miscarried during adolescence. They found that conditional on becoming pregnant during adolescence, having a child as a teen does not reduce mothers'

\footnotetext{
${ }^{7}$ More recently, Ashcraft, Fernández and Lang (2013) and Fletcher and Wolfe (2009) take into account the possibility that women have an abortion before they miscarry.
} 
education - in fact, women who give birth have slightly more years of schooling than those who miscarried.

In this paper, we estimate the effects of adolescent motherhood on education outcomes in Chile. Given that in Chile there is no data set that can be used to implement a quasi-natural experiment, we control for selection bias with the two empirical methodologies that our data permits: first, we construct a control group with propensity score matching and second, we control for environmental unobservable factors by including family fixed effects among a large sample of sisters. As an additional attempt to control for selection, we also estimate whether conditional on becoming mother before age 25, the timing of birth-during or after adolescence — affects the mother's education outcomes.

Our results reveal that in Chile, adolescent motherhood reduces the mother's future education outcomes, even after controlling for unobservable characteristics. As a baseline, we estimate cross-section estimates that control for individual, family and environmental characteristics, and find that women who gave birth as teens have one less year of schooling, are $31 \%$ less likely to graduate from high school, and are $49 \%$ less likely enroll in post-secondary education, compared to women of similar backgrounds who did not have a teen birth. Our estimates from propensity score matching are almost identical to those from OLS.

Once we control for unobserved family-level and environmental factors, the effects of teen motherhood are reduced in half: sisters who had a teen birth had half a year less education, and were $17 \%$ less likely to graduate from high school and $28 \%$ less likely to enroll in postsecondary schooling, compared to sisters that did not have a teen birth. These results reveal that selection into motherhood is important, but that giving birth during adolescence reduces future education outcomes. If we further condition our results on being a mother, i.e., compare outcomes of sisters who gave birth before 25 years of age, we find that the timing of a birth 
matters: giving birth in adolescence has an important, negative effect on high school completion. Finally, we perform estimations across two observable dimensions of in the data: household poverty status and educational attainment of the grandmother in the household. We find that the negative effects of teen motherhood are concentrated among groups that are particularly vulnerable: poor and low educated households.

The following section contains background information regarding recent trends in teenage births and high school completion in Chile. In section 3 we describe the empirical methodologies, while the data and variables constructed are described in section 4 . Section 5 presents our empirical findings, and we close the paper with a section of concluding comments and policy implications.

\section{Adolescent motherhood and education outcomes in Chile}

Chile has made important advances regarding secondary school attendance and completion. During the 1990-2009 period, the rate of high school attendance among adolescents increased from 70 to 83 percent, with only slight differences by sex (Table 1). This can be attributed to large increases in educational investment and to compensatory programs targeted at the more vulnerable population, which is reflected by the narrowing gap between the poor and non-poor over the 20-year period. ${ }^{8}$

\section{[TABLE 1 HERE]}

Despite large public expenditures to increase households' demand for secondary education, Table 1 also reveals that high school completion remains a challenge. Almost 83 percent of high-school aged teens attend school, yet only 74.5 percent complete their secondary education by age 20. A greater proportion of girls complete high school relative to boys (77.5

\footnotetext{
${ }^{8}$ Source: World Bank (2006). Total educational expenditure increased from 4 to 7.6 percent of GDP between 1990 and 2002.
} 
percent vs. 71.5 percent), and even though it has been substantially reduced during the last 20 years, a gap still remains between the poor and non-poor: only 67.1 percent of poor youths finish high school, compared to 80.3 percent of those from non-poor families.

Among girls, attendance and high school completion are related to pregnancy. According to the CASEN surveys during the 1990-2009 period, when asked what was the most important reason for not attending school, almost 21 percent of valid responses among high-school aged girls were motherhood or pregnancy, followed by economic problems (Table 2). In the 2009 survey, 30 percent of girls cite pregnancy and motherhood as the most important reason for leaving school. ${ }^{9}$

\section{[TABLE 2 HERE]}

During the period we analyzed, an average of 21.1 percent of adolescent girls became mothers by age 19 (Table 3), although the incidence of teen motherhood showed an increasing trend during the 1990s before it declined: between 1990 and 1998, the share of adolescent motherhood increased from about 22 to 25 percent, followed by a rapid decline to 17 percent by 2009. As is the case in other countries, in Chile the incidence of teen motherhood is closely related to poverty: 30.1 percent of poor girls were mothers by age 19, compared to about 18 percent of non-poor girls, an incidence rate that is 70 percent higher among the poor.

\section{[TABLE 3 HERE]}

In this paper, we analyze the short-term consequences of teen motherhood on mother's education outcomes among women aged 20 to 24 years. During this age period, a high proportion of young women become mothers. In fact, by the time they reach 24 years of age, 57 percent of women are mothers in Chile, with sharp differences between income groups (Table 4): 76 percent

\footnotetext{
${ }^{9}$ Source: author's estimates based on the 2009 CASEN.
} 
of poor women are mothers by age 24 , compared to 50 percent of non-poor women of the same age. The gap across poverty groups, however, has declined rapidly in recent years.

\section{[TABLE 4 HERE]}

Young motherhood is negatively correlated to education outcomes (Table 5). Women who delay motherhood beyond age 24 are more likely to complete their secondary education relative to those who become mothers by age 24 : data reveals that 76 percent of women that are not yet mothers finish high school, compared to 45 percent of young mothers. Also, women who are not mothers at age 24 are four times more likely to enroll in post-secondary education: 42 percent compared to 11 percent of young mothers, and they obtain 2.3 years of additional years of schooling on average.

Conditional on becoming a mother by age 24 , women who delay childbirth beyond adolescence have better education outcomes than those who had their first child in their teens. As observed in Table 5, relative to adolescent mothers, a higher share of young mothers completed high school (55 vs. 32 percent), enrolled in post-secondary schooling (14 vs. 5 percent), and completed an additional 1.3 years of schooling by age 24 . These stylized facts suggest that (i) becoming a mother by age 24 is costly in terms of education outcomes, and (ii) that having a child during adolescence has higher costs than delaying motherhood by 5 years.

\section{[TABLE 5 HERE]}

But does delaying birth beyond the teenage years have a causal negative effect on women's human capital? Or are young mothers different from young women who are not moms in their youth? As discussed earlier, this is a difficult question to answer empirically due to both methodological challenges and, in the case of less developed countries, lack of ideal data. Nonetheless, in the following section we discuss the methodologies that we employ to answer this question. 


\section{Empirical Methodology}

We are interested in estimating the effect of giving birth as an adolescent on the mother's education outcomes. Establishing causality is difficult because adolescent motherhood is not a random event, and because one cannot observe the counterfactual-i.e., what the mother's education outcome would have been had if she had not given birth. Previous research has found that girls who become mothers in adolescence are different from girls that postpone motherhood until later in life in terms of observable characteristics (socio-economic backgrounds and community characteristics), and possibly in terms of unobservables.

If teenage motherhood was a random event, the estimation would be straightforward:

$$
Y_{i}=\alpha+\beta M_{i}+\phi X_{i}+\varepsilon_{i}
$$

where $Y_{i}$ is the outcome of interest, and $\mathrm{M}_{\mathrm{i}}$ is an indicator variable that equals one if the woman gave birth as a teen, and $\mathrm{X}_{\mathrm{i}}$ includes variables that measure individual characteristics such as age, background factors such as the family's socio-economic status, community characteristics, rural location, etc. To the extent that motherhood requires time (for child care duties) that detracts from academic activities, being a mother $\left(\mathrm{M}_{\mathrm{i}}\right)$ is also a determinant of education outcomes, and $\beta$ captures the effect of having a child as a teen on these outcomes.

One could estimate (1) with least squares or Probit or Logit regressions. However, if unobservable characteristics (such as women's motivation, ability, or preferences towards fertility) are correlated both with the likelihood of becoming a teen mother and with education outcomes then $\beta$ is a biased estimate of teen motherhood effects.

In this paper, we first estimate equation (1) with OLS to obtain a baseline estimate of $\beta$, which captures the conditional correlation between teenage motherhood and the mother's education outcomes, conditional on her age and on family and community characteristics. Then 
we control for selection with two different methodologies: first, we construct a better control group than all other available woman using propensity score matching. As a second methodology, we control for selection bias into motherhood by comparing education outcomes of sisters that were adolescent mothers with those that were not, by including a family fixed effect in our regressions.

The most recent research on the effects of teen motherhood compares outcomes of women who became pregnant as teens and gave birth, with those of women who miscarried. The premise behind these papers is that women who become pregnant are different from those who don't, so that analyzing outcomes of those who were potential mothers controls for selection into motherhood. Our data does not have information on pregnancies that end in miscarriage or abortion, ${ }^{10}$ but we attempt to follow the notion behind this line of research by analyzing the effect of the timing of a birth among young mothers' outcomes-i.e., we compare education outcomes of all women aged 20 to 24 who are mothers, controlling for whether their first birth occurred in adolescence. Limiting the analysis to young mothers (aged 14 to 24) controls for selection into motherhood - at least partially and up to age 24-since this sub-group of women has selected into early motherhood. ${ }^{11}$

\section{Data, variables, and sample constructed}

To estimate the short-run effects of becoming a mother in adolescence, we need information about a young woman's family background characteristics when she was an

\footnotetext{
${ }^{10}$ Abortion is illegal in Chile, and no systematic data is collected regarding its incidence. However, unofficial estimates suggest that between 27.3 and 63.6 induced abortions per 1,000 women aged 15-49 take place in Chile each year (about 96,000 to 224,000 induced abortions in total), making it the second highest abortion rate in Latin America (Singh and Wulf, 1994).

${ }^{11}$ Birth control is provided for zero cost at public health centers beginning at age 14, so that all women are able to avoid a pregnancy if they so desire. The most recent National Youth Survey (INJUV, 2010) reports that over 75\% of young, sexually active women used birth control in their most recent sexual encounter and among those that did not (aged 24 or less), only $8 \%$ did so intentionally to become pregnant and only $2.5 \%$ they do not know how to avoid pregnancy or how to obtain birth control methods (Source: Graph 173 and Table 130 in INJUV, 2010. The age-group average is weighted by the age group distribution.)
} 
adolescent, the age when she first became a mother, and her subsequent education and labor market outcomes. Ideally, this information would come from longitudinal data where the woman and her family are observed when she was a teenager, and again when the woman is an adult and her motherhood status is observed. In Chile, we do not have longitudinal data with such rich information on the young woman and her family, so we constructed a retrospective family history for young women aged 20-24 who still live with their parents (specifically, their mothers) so that we are able to observe individual as well as family-level characteristics. We construct a large sample from nine repeated rounds of Chilean CASEN household surveys that span the 1990-2009 period, ${ }^{12}$ which contains individual and family-level information about education, health, employment and income as well as the household's demographic composition.

Limiting the sample to young women aged 20 to 24 years that still live with their parents could be problematic in the empirical estimations for various reasons. First, youths living in their parents household might be different from those who have moved away, and if so, how are they different? In addition, how do young women living at home fare relative to all women in that age group? In the Latin American context, it is very common for young men and women to live with their parents until their mid- to late 20s. According to the Chilean National Survey of Youth fielded in 2009, 74 percent of youth aged 20 to 24 live with their parents, only 12 percent live independently in their own home, and the remaining 14 percent live with either other relatives, in-laws, or friends (INJUV, 2010). Among those that still live with their parents, more than 30 percent has never considered the possibility moving away from home.

Nonetheless, a potential empirical problem regarding the sample constructed is that young women who move away from home may be different from those that stay, especially if her decision is correlated to whether she has a child or not. Our empirical estimations would be

${ }^{12}$ CASEN is the abbreviation for National Socioeconomic Characterization surveys (Caracterización Socioeconómica Nacional). This paper uses CASENs household surveys fielded in 1990, 1992, 1994, 1996, 1998, 2000, 2003, 2006 and 2009. 
biased if relative to those that leave their parents' home, girls that remain living with their parents have "worse" unobservable characteristics: if girls that stay are less motivated, less assertive or less independent than those that move away, then they are also more likely to do poorly in school and in the work force, and would have worse observed education and labor outcomes, so that part of the estimated "effect" of being a teen mother is due to these unobservable characteristics.

Table 6 reveals that among young women who are not mothers by age 24, only 7.7 percent have moved away and live on their own, while among those who are moms-both adolescent and young moms - about 42 percent live with their parents, and 58 percent live independently. ${ }^{13}$ This reveals that motherhood is correlated to whether girls live with their parents, which is not surprising given that the most important reason for moving away from parents' homes is to form a family: according to the 2009 National Youth Survey, 68 percent of young women that moved away from home did so to form their own home (INJUV, 2010). ${ }^{14}$

These stylized facts confirm that there is selection bias in the decision of remaining to live with one's parents. However, unlike more developed countries, in Chile the young women that remain living with their parents-including those who are mothers-have better education outcomes relative to girls who move away: they are more likely to graduate from high school, enroll in college or a university, and have more years of schooling (Table 6). These results reveal that the women in our sample have better observed human capital outcomes than those excluded from the sample - both on average and among mothers. Thus, if there is a selection bias from including only women who live with their parents, the negative effect of motherhood is probably underestimated in our sample: the young women we include have the economic, logistic, and personal support of their parents and other family members, which ameliorates the detrimental

\footnotetext{
${ }^{13}$ Living independently means the young woman is either the head of her own household or the spouse of the head of the household.

${ }^{14}$ Own estimates based on valid responses in Table 106 of INJUV (2010). Additionally, the National Youth Survey finds that among youths still living at home, almost 80 percent of those who have one child wish to move away from their parents' home, compared to 58 percent of those who do not have children (see Table 103 of INJUV, 2010).
} 
effect of motherhood on education outcomes.

[TABLE 6 HERE]

\section{Individual Variables}

The dependent variables we analyze are (i) high school completion, which is a binary variable that equals one if the woman finished her high school education; (ii) whether she has ever enrolled in a post-secondary education program (either at a college, university, or technical institute); and (iii) years of education completed.

The CASEN survey is designed to measure socio-economic status and access to various social programs in Chile, but it does not contain a woman's complete fertility history. We construct a woman's motherhood status from the survey's household composition section. Multifamily households are common in Chile, ${ }^{15}$ so that individuals are asked to identify their relationship to the head of the household and to the head of their nuclear family unit. Mothers are women aged 20 to 24 years of age who are either: (i) the head of their household (or spouse) and sons or daughters are present, or (ii) they are the head of their nuclear family within a larger household, and sons/daughters are present in their nuclear family unit. We also estimate the woman's age at first birth, ${ }^{16}$ so we define a teenage mother if her first child was born before age 20. We also include the young woman's age in the estimations and set of dummies for the year of birth of the mother to control for cohort effects.

\section{Family characteristics}

Family variables include information about the household's demographic composition (number of teenagers, number of other young adults aged 20-24, number of adults and number of

\footnotetext{
${ }^{15}$ In Chile, $17 \%$ of households had more than one family unit.

16 This is estimated from the difference between the young woman's age and the age of the child (or oldest child, if she has more than one), as this information is not directly reported in the data.
} 
elderly in the household). ${ }^{17}$ We also control for education attainment of the head of the household and of the woman's mother, henceforth referred to as the grandmother, a variable for whether the head of the household is female, total adult household income and whether the household is poor. We also include two variables that describe the grandmother: her age at first birth, ${ }^{18}$ and her age when she gave birth to the woman in our sample. ${ }^{19}$

We also controlled for household density (defined as the number of persons in the household per number of bedrooms) as a proxy for household wealth. ${ }^{20}$ Variables that capture environmental characteristics included a dummy for rural location and municipality fixed effects. $^{21}$ Additionally, to control for changes in economic conditions as well as for long-term trends in school enrollment and motherhood, we included a set of region-year effects in all estimations.

\section{Sisters}

We implement a sister's fixed effect model to control for unobservables at the household level. One concern of this exercise is the external validity of the findings as the group of sisters, and thus households with more than one sibling, might differ systematically from the average household. Table 7 reports summary statistics of outcomes and observed characteristics for all women in our data set as well as for our sample of sisters, and by their maternity status. They indicate that women in the sample of sisters have slightly lower educational attainments. In terms of their observed characteristics differences are mixed. As expected they come from larger

\footnotetext{
${ }^{17}$ We exclude number of young children aged 12 or younger because this is potentially endogenous to the motherhood variable.

${ }^{18}$ Grandmother's age at first birth is estimated as the difference between the age of the young woman's mother (grandmother) and the age of the oldest child in the household, so that the variable underestimates the grandmother's age at first birth if older sons or daughters have moved away from the household at the time of the survey (the survey does not collect any information of people living outside the household).

${ }^{19}$ Age of the grandmother when she gave birth to the woman in our sample is estimated as the difference in the age of the young woman and her mother at the time of the survey.

${ }^{20}$ Studies have found that household density and sexually promiscuous behaviors are correlated and prevalent in Chile's public housing (ECLAC 2005).

${ }^{21}$ Chile is divided into 15 administrative regions, which is each then sub-divided into provinces and a total of 345 municipalities.
} 
households. Their head of the household and their mother has more education, and they are less likely to have a female as head of the household, but they have a lower per capita income and thus come from poorer households. Therefore, it is not clear how this sample might bias our estimates in any specific direction, and secondly, differences are small across these two samples.

\section{[TABLE 7 HERE]}

\section{Empirical Results}

The methodological challenge of estimating the effect of motherhood on schooling (and other human capital) outcomes is identification, disentangling the causality of being a mother from an adolescent's unobserved characteristics that may be driving both the motherhood and schooling decisions. Given that we want to focus our discussion on the impact of motherhood on educational outcomes, we report only the estimates for the impact of motherhood status in Tables 8 through $10 .^{22}$ In all tables, columns labeled OLS report results from a linear estimation of the correlation of motherhood and each outcome controlling for individual, family, and community characteristics. The set control variables includes a woman's age, years of education of the head of household, years of education of the grandmother, the grandmother's age at first birth, grandmother's age when the woman in our sample was born, a dummy variable for femaleheaded households, number of teens in the household, number of other youth aged 20-24 in the household, number of adults (aged 25-59) in household, number elderly (age 60+) in the household, a measure of household density (persons per bedroom), a dummy for rural location, the woman's year of birth to control for cohort effects, municipality fixed effects, and full set of region-year controls.

In Tables 8 through 10 we report the results from three different empirical methodologies and for three different samples. In all tables, columns labeled "OLS" report the conditional

\footnotetext{
${ }^{22}$ Results for other control variables have the expected sign and available upon request.
} 
correlation between adolescent motherhood and educational outcomes. If there is selection bias, the OLS coefficients over-estimate the true effect of teen motherhood. Columns labeled "Matching" include results from the propensity score matching estimate of the average treatment effect for the treated performed using the five nearest-neighbors. ${ }^{23}$ Matching estimates attempt to generate a better control group for adolescent mothers than the standard regression analysis. Finally, columns labeled "Sisters" report within-family fixed effects estimates, which also control for the woman's age and year of birth, which reduce the bias do to unobservables at the family level.

We perform each estimation for three different samples. The first sample (Full sample) includes all women aged 20-24 that live with their mothers. This is the largest sample $(\mathrm{N}=41,516)$ and serves as the benchmark estimate that does not control for any selection bias; it's intended to obtain the average effect of teen motherhood. The second sample (Mothers) includes only women that are mothers by age 24 - both women who became mothers as teens or between ages 20 and 24. This allows us to reduce the bias arising from selection into motherhood, and to estimate a whether the timing of motherhood is relevant on educational outcomes. The third sample (Teen mothers and non-mothers) excludes women that became mothers between ages 20 to 24 , and is used to compare adolescent mothers with woman that are not yet mothers.

\section{[ TABLE 8 ]}

Similar to previous findings in the literature, column 1 of Table 8 reveals that the conditional correlation of adolescent motherhood and the three education outcomes we analyze is negative. The probability of obtaining a high school diploma is 0.22 lower-31 percent-for women aged 20 to 24 who were adolescent mothers compared to those women that were not. We

\footnotetext{
${ }^{23}$ In order to estimate the propensity score we performed a estimation of the probability of becoming and adolescent mother controlling on the same observables as described for the OLS estimates, and then constructed the control group using five nearest-neighbors procedure. Results are robust to other matching procedures such as single nearestneighbor and kernel matching. Appendix A reports estimates of the propensity score and results of the covariate balancing test and the absolute bias reduction achieved with the five nearest-neighbors matching procedure.
} 
estimated and discuss below the marginal effects, which we estimate by dividing the coefficient with the mean of the dependent variable (x 100). For instance, in the case of high school diploma, the marginal effect is $-0.2214 \div 0.704 \times 100=31 \%$ (Table 8 , column 1 ). Women who were teen moms are also 49 percent less likely to be enrolled in post-secondary education, and they have 1.1 less years of schooling, which represent 9 percent less education attainment.

Column 2 reports matching estimates, showing that conditional on the observables that we use to estimate the propensity score and to construct the comparison group, the effect of adolescent motherhood is slightly lower — and not significantly different from - than the one obtained using a linear estimate. One of the reasons that might explain the small reduction in the bias using a matching estimator comes from the difficulty of obtaining a large and comprehensive set of pre-treatment variables. As CASEN surveys collect mainly contemporaneous information about household members, we are unable to account for all the covariates that affect the likelihood of becoming and adolescent mother and that affect educational outcomes. The Sisters estimates in column 3, which reduce the bias by accounting for contemporaneous and pretreatment unobservables at the family level, show that the impact of teen motherhood is about half of the effect estimated with OLS and matching. Teen mothers are 17.5 percent less likely to have completed high school relative to other women, they are 28 percent less likely to be enrolled in post-secondary education, and they have 0.45 less years of schooling.

Our second sample includes only mothers (only women that become mothers at any age before turning 25), and results show smaller point estimates of the effect of teen motherhood. The OLS and matching estimates of this sample (columns 4 and 5) find that teen motherhood reduces the likelihood of high school completion by 30 percent, reduces the probability of being enrolled in post-secondary education by 38 percent, and decreases years of schooling by 6.8 percent relative to a woman that became mother between ages 20 and 24. Column 6 presents the results 
that compare Sisters who are both mothers but who timed their births differently, i.e. pairs of sisters in which one of them became an adolescent mother and the other became a mother when she was between 20 and 24 years old. This estimation controls for unobservables at the family level and for selection into motherhood. Results indicate that teen mothers are 18 percent less likely to have completed high school, but that the impact on post-secondary education and years of schooling is no longer distinguishable from zero. A possible explanation for the lack of statistical significance on these estimates could be the relatively smaller sample size, as we are reducing the sample only to sisters that are also mothers.

In the third sample (columns 7 through 9) we compare outcomes of teen mothers with women that have not yet become mothers by age 24 . We use this sample to corroborate that there is a selection bias into motherhood, as we are comparing outcomes of teen mothers with the group of women against whom the selection bias into motherhood should be stronger. As expected, we observe a small increase in both the point estimates and the marginal effect, relative to the Full sample (and also to the Mothers's sample). Here the effects seem again to be better identified as the sample size increases significantly with respect to the sample of mothers.

Overall, results are in line with what previous literature has found in developed countries. As we control for the selection into motherhood and family unobservables, a large fraction of the negative effect is eliminated for all three outcomes. However, sizeable large and negative effects are still present as a result of adolescent motherhood. Particularly strong is the effect on high school completion, while somewhat less clear effects on post-secondary education and total years of schooling completed. As our study includes only women aged 20 to 24 years, and they are still in phase in their life cycle in which tertiary education is a more contemporaneous outcome (and thus also years of schooling), it would be natural to expect a stronger effect of adolescent motherhood on past outcomes, such as high school completion, than in more contemporaneous 
ones.

\section{Heterogeneous Effects of Teen Motherhood}

In addition to estimating the average effect of adolescent motherhood, we estimate the impacts on different subsamples to see if there are heterogeneous effects of teen motherhood. We performed estimates across poverty status (Table 9), and by educational attainment of the grandmother (Table 10). Households where the grandmother has 12 or more years of education were classified as having a High education level, and all other households were classified as Low education.

Our analysis across poverty groups (Table 9) finds that high school completion is more affected among poor families than non-poor ones. Once family unobservables are controlled for, we find that having a child in adolescence reduces the likelihood of completing high school by 32 percent in poor households, compared to a 13 percent in non-poor households (columns 3 and 4). The negative effect for poor household still holds if we also control for selection into motherhood as well as for family unobservables (column 7): a teen birth reduces high school completion probability by 31 percent, but only among the poor.

For enrollment in post-secondary education, the effect is larger for non-poor families both in term of point estimates, but the marginal effect is greater among poor women, who are $54 \%$ less likely to enroll in college as a result of a teen birth compared to non-poor women who are $26 \%$ less likely to enroll (columns 3 and 4). This result is not surprising when we account for the fact that post-secondary education in Chile is more expensive and thus more easily accessible to wealthier families, so that the negative marginal effect of adolescent motherhood should have a stronger impact among those families with less financial resources. Once we control for selection into motherhood and family unobservables (columns 7 and 8), point estimates decrease substantially rendering the effect insignificant. A similar situation is obtained for years of 
schooling.

The analysis across education levels of the grandmother (Table 10) yield similar results than those by poverty status. The impact on high school completion is significant for families with lower educational levels in both samples. A teen mother from a household with low educational level is 26 percent less likely to have completed high school (column 7) than a sister that became mother later in her youth. The negative effect is also present in terms of years of schooling, with 0.44 fewer years of schooling (4.4 percent less) as a result of a teen birth among poor sisters. For post-secondary education the effect is not significant.

\section{Concluding Comments}

This paper analyzed the effect of teen motherhood on education outcomes of women aged 20 to 24 years during the 1990-2009 period in Chile. Taking advantage of a large data set we constructed from repeated rounds of nine household surveys, we are able to estimate the impact of teen motherhood on high school completion, post-secondary enrollment, and years of schooling. As the literature on the impacts of motherhood on human capital accumulation recognizes, there are important difficulties estimating the causal effect as motherhood as it cannot be treated as a completely random event. In order to overcome the selection bias in our data set we follow a twofold strategy. First we implement three different estimation procedures: linear regression, matching, and a sister fixed effect model. The linear regression model estimates the conditional correlation of teen motherhood on education outcomes, while matching estimations are performed in order to construct a better comparison group than the overall sample that is used in the OLS estimates as a counterfactual. The sisters fixed effects estimation controls for family level unobservables, thus reducing the selection bias present in OLS and matching estimations. Second, we perform estimations on three different samples. First we use all women aged 20 to 24 
years as a benchmark for our estimates. Then we estimate the effects on a sample composed of only those women that are mothers. We argue that this sample reduces the selection bias into motherhood - at least up to the upper bound of our sample, i.e. age 24. The third and last sample includes teen mothers and those that have not yet become mothers, and helps us to check whether there is a selection bias into motherhood as we eliminate later mothers from our sample.

Our results are in line with the existing literature: when we control for family unobservables and selection into motherhood by estimating a model with sisters fixed effect on the sample of mothers, there are significant and sizeable negative effects on educational outcomes, particularly on high school completion: conditional on becoming a mother, teenage childbirth reduces the likelihood of obtaining a high school diploma by 18 percent. Also as expected, in as much as there exists a significant role of unobservables, linear estimates cannot be viewed as capturing the causal effect of teen motherhood.

In addition, we analyze whether there are heterogeneous effects across poverty status and education of level of the grandmother in the household. Our analysis across poverty groups indicates that a teenage birth reduces high school completion by about 31 percent, and the effect is present only among women living in poor households. There are also heterogeneous effects across education levels: women living in household with lower levels of educational attainment of the grandmother experience significant negative effects from a teen birth on high school completion and years of education, and the effects are large. A teen mother from a household with low educational level is 26 percent less likely to have completed high school than a sister that became mother later in her youth, and would have 0.44 fewer years of schooling.

Overall our study shows that early motherhood in Chile has significantly negative effects on at least high school completion and possibly on years of schooling, and that conditional on motherhood, the timing of a birth matters, as adolescent mothers are less likely to finish high 
school that those women that gave birth later in youth. The negative effects from adolescent motherhood are concentrated among poor and less educated households. Our findings suggest that public policies aimed at reducing teenage motherhood should have positive effects on women's education outcomes, especially among the poor. 


\section{References}

Ashcraft, A., Fernández-Val, I., Lang, K. 2013. The Consequences of Teenage Childbearing: Consistent Estimates When Abortion Makes Miscarriage Non-random. The Economic Journal, Vol. 123, Issue 571, pp.875-905.

Azevedo, J.P., Lopez-Calva, L.F., Perova, E. 2012. Is the baby to blame? An inquiry into the consequences of early childbearing. Policy Research Working Paper Series 6074. The World Bank.

Buvinic, M. 1998. The Costs of Adolescent Childbearing: Evidence from Chile, Barbados, Guatemala and Mexico. Studies in Family Planning, 29(2), pp. 201-209.

Chevalier, A., Viitanen, T.K. 2003. The long-run labour market consequences of teenage motherhood in Britain. Journal of Population Economics 16(2), pp.323-343.

ECLAC (Economic Commission for Latin America and the Caribbean). 2005. Políticas sociales de vivienda, pobreza y ciudadanía en Chile: Un estudio de caso desde la etnografía. Mimeo, Proyecto Regional de Población CELADE-UNFPA.

Fletcher, J.M., Wolfe, B.L. 2009. Education and Labor Market Consequences of Teenage Childbearing: Evidence Using the Timing of Pregnancy Outcomes and Community Fixed Effects. Journal of Human Resources. Vol. 44(2), pp. 303-325.

Geronimus, A.T., Korenman, S. 1992. The Socioeconomic Consequences of Teen Childbearing Reconsidered. Quarterly Journal of Economics. 107(4), pp.1187-1214.

Geronimus, A.T., Korenman, S. 1993. The Socioeconomic Consequences of Teen Childbearing: Evidence and Interpretation. Demography. 30(2), pp.281-290.

Grogger, J., Bronars, S.G. 1993. The socioeconomic consequences of teenage childbearing: findings from a natural experiment. Family Planning Perspectives, 25(4), pp.156-161,174.

Hoffman, S.D. 1998. Teenage Childbearing is not So Bad After All...Or Is It? A Review of the New Literature. Family Planning Perspectives, 30(5), pp.236-239,243.

Hoffman, S.D., Foster, E.M., Furstenberg, F.F. 1993. Reevaluating the Costs of Teenage Childbearing. Demography. 30(1), pp.1-13.

Hotz, V. J., McElroy, S.W., Sanders, S.G. (2005). Teenage Childbearing and Its Life Cycle Consequences: Exploiting a Natural Experiment. Journal of Human Resources, 40(3), pp.683-715.

Instituto Nacional de la Juventud (INJUV). 2010. $6^{a}$ Encuesta Nacional de la Juventud. 
Available from http://www.injuv.gob.cl/injuv2010/encuestas_juventud

Klepinger, D., Lundberg, S., Plotnick, R. 1999. How Does Adolescent Fertility Affect the Human Capital and Wages of Young Women? The Journal of Human Resources 34(3), pp. $421-448$

Lee, D. 2010. The early socioeconomic effects of teenage childbearing: A propensity score matching approach. Demographic Research 23, pp 697-736.

Levine, D.I., Painter, G. 2003. The Schooling Costs of Teenage Out-of-Wedlock Childbearing: Analysis with a Within-School Propensity-Score-Matching Estimator. Review of Economics and Statistics, 85(4), pp.884-900.

MIDEPLAN (Ministerio de Planificación). 2003. Adolescentes y jóvenes que abandonan sus estudios antes de finalizar la enseñanza media: Principales tendencias. Mimeo. http://www.mideplan.cl/casen/pdf/desercionescolar.pdf

Olsen, Randall J. and George Farkas. 1989. Endogenous Covariates in Duration Models and the Effect of Adolescent Childbirth on Schooling. Journal of Human Resources 24(1), pp. 39-53.

Ribar, D. 1994. Teenage Fertility and High School Completion. The Review of Economics and Statistics 76(3), pp.413-424.

Rosenzweig, Mark R., and Wolpin, Kenneth I. 1995. Sisters, Siblings, and Mothers: The Effect of Teen-Age Childbearing on Birth Outcomes in a Dynamic Family Context. Econometrica , 63 (March), pp. 303-26.

Singh, S. 1998. Adolescent childbearing in developing countries: a global review. Studies in Family Planning, 29(2), pp.117-36.

Singh, S., Wulf, D. 1994. Estimated Levels of Induced Abortion in Six Latin American Countries. International Family Planning Perspectives, 20(1), pp. 4-13.

The World Bank. 2006. Chile Development Policy Review, Volume II. Report No. 33501-CL. Washington, D.C. 
Table 1. Chile: High school attendance and completion 1990 - 2009, by sex and poverty status

\begin{tabular}{|c|c|c|c|c|c|c|c|c|c|c|c|c|}
\hline \multirow[b]{2}{*}{ Year } & \multicolumn{6}{|c|}{ High school attendance } & \multicolumn{6}{|c|}{ High school completion } \\
\hline & Average & Men & Women & Not poor & Poor & $\begin{array}{c}\text { Poor/non- } \\
\text { poor }\end{array}$ & Average & Men & Women & Not poor & Poor & $\begin{array}{c}\text { Poor/non- } \\
\text { poor }\end{array}$ \\
\hline 1990 & 70.4 & 69.8 & 71.0 & 73.1 & 67.0 & 0.92 & 40.5 & 39.3 & 41.7 & 54.2 & 23.5 & 0.43 \\
\hline 1992 & 68.9 & 68.3 & 69.6 & 71.5 & 65.1 & 0.91 & 43.1 & 39.5 & 46.7 & 54.8 & 33.1 & 0.60 \\
\hline 1994 & 70.1 & 69.6 & 70.6 & 72.1 & 67.0 & 0.93 & 45.9 & 43.6 & 48.1 & 57.3 & 32.2 & 0.56 \\
\hline 1996 & 74.9 & 74.4 & 75.4 & 78.1 & 68.3 & 0.87 & 50.0 & 46.6 & 53.4 & 60.8 & 31.8 & 0.52 \\
\hline 1998 & 76.9 & 76.2 & 77.6 & 79.4 & 70.9 & 0.89 & 52.9 & 50.0 & 55.8 & 63.4 & 34.4 & 0.54 \\
\hline 2000 & 77.8 & 77.0 & 78.7 & 79.4 & 74.7 & 0.94 & 54.2 & 50.1 & 58.5 & 64.6 & 42.6 & 0.66 \\
\hline 2003 & 82.7 & 82.6 & 82.8 & 83.5 & 80.9 & 0.97 & 63.5 & 59.5 & 67.5 & 73.3 & 48.7 & 0.66 \\
\hline 2006 & 83.5 & 82.3 & 84.8 & 84.3 & 80.5 & 0.96 & 71.0 & 68.3 & 73.8 & 77.3 & 53.0 & 0.69 \\
\hline 2009 & 82.8 & 81.8 & 83.9 & 83.4 & 80.8 & 0.97 & 74.5 & 71.5 & 77.5 & 80.3 & 67.1 & 0.84 \\
\hline
\end{tabular}

Source: CASEN surveys. Attendance: percent of high school-aged youths (15-18 years old) that attend high school. Completion: percent of youths aged 20 years that finished high school. Poverty status based on poverty line defined by the Ministry of Social Development. 
Table 2. Adolescent girls: Reasons for not to attend to school , $1990-2009$

Reason

$\%$ Valid responses

Maternity/pregnancy

20.9

Economic difficulty

18.3

Helps with domestic chores

16.6

Works/seeks employment

16.2

Not interested

9.5

Other

6.0

Personal or academic problems

5.8

Disability, illness, or special needs

4.0

No schools/difficult access

2.8

Source: CASEN surveys 1990-2009. Most important reason for not attending high school among high-school aged girls (15 to 18 years.) 
Table 3. Adolescent motherhood 1990 - 2009, by poverty status

\begin{tabular}{c|c|cc}
\hline Year & All women & Not poor & Poor \\
\hline 1990 & 21.8 & 16.0 & 30.1 \\
1992 & 22.7 & 18.0 & 29.9 \\
1994 & 22.8 & 18.2 & 30.7 \\
1996 & 21.1 & 17.2 & 31.8 \\
1998 & 24.8 & 21.6 & 34.1 \\
2000 & 23.8 & 19.7 & 33.5 \\
2003 & 21.5 & 18.0 & 31.4 \\
2006 & 18.2 & 16.3 & 26.3 \\
2009 & 16.8 & 15.0 & 23.6 \\
\hline Average & $\mathbf{2 1 . 1}$ & $\mathbf{1 7 . 7}$ & $\mathbf{3 0 . 1}$ \\
\hline
\end{tabular}

Source: CASEN surveys. Percent of adolescent girls aged 19 years old that are mothers. Poverty status based on poverty line defined by the Ministry of Social Development. 
Table 4. Young motherhood 1990 - 2009, by poverty status

\begin{tabular}{c|c|ccc}
\hline Year & All women & Not poor & Poor & $\begin{array}{c}\text { Poor/Non- } \\
\text { poor }\end{array}$ \\
\hline 1990 & 57.9 & 46.1 & 76.9 & 1.67 \\
1992 & 57.8 & 46.1 & 78.6 & 1.70 \\
1994 & 60.2 & 49.3 & 79.4 & 1.61 \\
1996 & 58.8 & 53.2 & 75.1 & 1.41 \\
1998 & 61.1 & 55.8 & 78.5 & 1.41 \\
2000 & 58.7 & 53.3 & 74.8 & 1.40 \\
2003 & 58.2 & 53.1 & 74.9 & 1.41 \\
2006 & 53.1 & 49.5 & 75.8 & 1.53 \\
2009 & 47.4 & 45.1 & 59.9 & 1.3 \\
\hline Average & $\mathbf{5 6 . 7}$ & $\mathbf{5 0 . 4}$ & $\mathbf{7 5 . 6}$ & $\mathbf{1 . 5}$ \\
\hline
\end{tabular}

Source: CASEN surveys. Percent of young women aged 24 years old that are mothers.

Poverty status based on poverty line defined by the Ministry of Social Development. 
Table 5. Education outcomes of young women, by motherhood status

\begin{tabular}{l|cc|cc}
\hline Variable & $\begin{array}{c}\text { Is not a } \\
\text { mother }\end{array}$ & $\begin{array}{c}\text { Is a } \\
\text { mother }\end{array}$ & $\begin{array}{l}\text { Became mother... } \\
\text { youth }\end{array}$ & ...as teen \\
\hline Obtained high school diploma & 0.76 & 0.45 & 0.55 & 0.32 \\
Enrolled in post-secondary educ. & 0.42 & 0.11 & 0.14 & 0.05 \\
Years of schooling & 12.4 & 10.1 & 10.6 & 9.3 \\
\hline
\end{tabular}

Source: CASEN surveys. Includes women aged 24 years old that are (i) not mothers, (ii) became mothers as youths aged 20-24, or (iii) who became mothers in adolescence. 
Table 6. Summary Statistics - Women aged 20 to 24 years, 1990-2009

\begin{tabular}{|c|c|c|c|c|c|c|c|}
\hline \multirow{3}{*}{ Variable } & \multicolumn{3}{|c|}{ Women who are: } & \multicolumn{2}{|c|}{ Women who: } & \multicolumn{2}{|c|}{ Mothers who: } \\
\hline & \multirow{2}{*}{$\begin{array}{c}\text { Not } \\
\text { mothers }\end{array}$} & \multicolumn{2}{|c|}{ Mothers } & \multirow{2}{*}{$\begin{array}{l}\text { Live with } \\
\text { parents }{ }^{a}\end{array}$} & \multirow{2}{*}{$\begin{array}{c}\text { Live on } \\
\text { their } \\
\text { own }\end{array}$} & \multirow{2}{*}{$\begin{array}{l}\text { Live with } \\
\text { parents }\end{array}$} & \multirow{2}{*}{$\begin{array}{c}\text { Live on } \\
\text { their } \\
\text { own }\end{array}$} \\
\hline & & As teen & As youth & & & & \\
\hline \multicolumn{8}{|l|}{ Motherhood and living status } \\
\hline Lives with parents & 0.923 & 0.421 & 0.447 & & & & \\
\hline Lives indpendently (own hhold.) & 0.077 & 0.579 & 0.553 & & & & \\
\hline Is a mother & & & & 0.274 & 0.849 & & \\
\hline Became mother as teen & & & & 0.144 & 0.496 & 0.526 & 0.584 \\
\hline Became mother between ages $20-24$ & & & & 0.130 & 0.353 & 0.474 & 0.712 \\
\hline \multicolumn{8}{|l|}{ Outcomes } \\
\hline Obtained high school diploma & 0.75 & 0.32 & 0.55 & 0.70 & 0.39 & 0.52 & 0.34 \\
\hline Enrolled in post-secondary education & 0.39 & 0.06 & 0.13 & 0.33 & 0.09 & 0.13 & 0.05 \\
\hline Years of schooling & 12.10 & 9.42 & 10.60 & 11.72 & 9.74 & 10.57 & 9.44 \\
\hline \multicolumn{8}{|l|}{ Observed characteristics } \\
\hline Age & 21.7 & 22.0 & 22.6 & 21.8 & 22.4 & 22.1 & 22.4 \\
\hline Education-Head of Hhold. (years) & 8.4 & 8.0 & 8.5 & 7.7 & 9.8 & 6.6 & 9.5 \\
\hline Education-Grandmother (years) & 7.9 & 7.9 & 8.5 & 7.6 & 9.4 & 6.5 & 9.4 \\
\hline Grandmother's age at first birth (years) & 24.9 & 20.4 & 22.8 & 24.9 & 19.0 & 24.7 & 19.0 \\
\hline Grandmother's age at woman's birth (years) & 27.1 & 10.9 & 12.5 & 26.9 & - & 26.6 & - \\
\hline Female-headed hhold. & 0.210 & 0.166 & 0.158 & 0.222 & 0.107 & 0.266 & 0.079 \\
\hline Adult income per capita ${ }^{b}$ & 114,889 & 46,744 & 56,473 & 100,646 & 52,534 & 55,952 & 47,076 \\
\hline Num. Teenagers in household & 0.619 & 0.273 & 0.321 & 0.661 & 0.014 & 0.640 & 0.014 \\
\hline Num. young adults in household & 0.412 & 0.280 & 0.336 & 0.414 & 0.242 & 0.385 & 0.239 \\
\hline Adults in household & 1.961 & 1.240 & 1.304 & 2.050 & 0.675 & 1.966 & 0.705 \\
\hline Num. elderly in household & 0.087 & 0.044 & 0.049 & 0.097 & 0.001 & 0.102 & 0.001 \\
\hline Num. Persons/bedroom & 1.692 & 2.276 & 2.071 & 1.875 & 1.980 & 2.227 & 2.148 \\
\hline Rural & 0.296 & 0.371 & 0.343 & 0.311 & 0.354 & 0.341 & 0.373 \\
\hline Poor household & 0.182 & 0.384 & 0.320 & 0.227 & 0.335 & 0.328 & 0.377 \\
\hline
\end{tabular}




\begin{tabular}{|c|c|c|c|c|c|c|c|}
\hline Num. Obs. & 34,139 & 12,748 & 14,361 & 43,752 & 17,496 & 12,018 & 15,091 \\
\hline
\end{tabular}

Source: Chile's CASEN surveys (1990, 1992, 1994, 1996, 1998, 2000, 2003, 2006 and 2009). Includes women aged 20-24 years that are (i) not mothers,

(ii) who became mothers in adolescence, or (iii) became mothers as youths aged 20-24. Observed characteristics include woman's age, education of

head of household, education of grandmother, age at first birth of grandmother, grandmother's age when woman was born, dummy variable for female head of household, number of teens in household (age 13-19), number of youth (age 20-24) in household, number of adults (age 25-59) in household, and number elderly (age 60+) in household, household density (persons per bedroom), dummy for rural location, and household poverty status. All differences across groups of motherhood status are statistically significant.

${ }^{a}$ Lives with parents: young women that report being the daughter of the head of the household. Lives independently: young women who report being the head of the household, or the spouse of the head of household.

${ }^{\mathrm{b}}$ Monthly adult income per capita includes income earned by household members aged 25 and older, divided by total household members, in 2009 Chilean pesos. Exchange rate 2009: CLP560/US\$. 
Table 7. Summary Statistics - All women and sisters aged 20 to 24 years, 1990-2009

\begin{tabular}{|c|c|c|c|c|c|c|c|c|c|}
\hline \multirow{3}{*}{$\begin{array}{l}\text { Variable } \\
\text { Outcomes }\end{array}$} & \multirow{2}{*}{\multicolumn{2}{|c|}{ All Women }} & \multicolumn{6}{|c|}{ Sisters } & \multirow{2}{*}{ t-test ${ }^{a}$} \\
\hline & & & \multicolumn{2}{|c|}{ All } & \multicolumn{2}{|c|}{ Not Mothers } & \multicolumn{2}{|c|}{ Mothers } & \\
\hline & Mean & Std. Dev. & Mean & Std. Dev. & Mean & Std. Dev. & Mean & Std. Dev. & \\
\hline Obtained high school diploma & 0.70 & 0.460 & 0.68 & 0.47 & 0.74 & 0.44 & 0.51 & 0.50 & $* * *$ \\
\hline Enrolled in post-secondary education & 0.33 & 0.468 & 0.31 & 0.46 & 0.37 & 0.48 & 0.11 & 0.32 & $* * *$ \\
\hline Years of schooling & 11.72 & 3.159 & 11.61 & 3.16 & 12.00 & 3.17 & 10.49 & 2.84 & $* * *$ \\
\hline \multicolumn{10}{|l|}{ Observed characteristics } \\
\hline Age & 21.790 & 1.4 & 21.711 & 1.385 & 21.619 & 1.376 & 21.977 & 1.379 & $* * *$ \\
\hline Education-Head of Hhold. (years) & 7.705 & 4.4 & 7.827 & 4.446 & 8.189 & 4.534 & 6.784 & 4.003 & $* * *$ \\
\hline Education-Grandmother (years) & 7.568 & 4.3 & 7.626 & 4.256 & 7.958 & 4.338 & 6.663 & 3.853 & $* * *$ \\
\hline Grandmother's age at first birth (years) & 24.871 & 6.3 & 23.548 & 5.303 & 23.713 & 5.262 & 23.069 & 5.393 & $* * *$ \\
\hline Grandmother's age at woman's birth (years) & 26.941 & 7.0 & 25.264 & 6.007 & 25.478 & 6.004 & 24.641 & 5.972 & $* * *$ \\
\hline Female-headed hhold. & 0.222 & 0.416 & 0.194 & 0.395 & 0.176 & 0.381 & 0.245 & 0.430 & $* * *$ \\
\hline Adult income per capita ${ }^{b}$ & 100646 & 208,908 & 86,795 & 186,765 & 100,545 & 210,734 & 47,094 & 72,463 & $* * *$ \\
\hline Num. Teenagers in household & 0.661 & 0.816 & 1.121 & 0.893 & 1.111 & 0.894 & 1.148 & 0.891 & $* *$ \\
\hline Num. young adults in household & 0.414 & 0.620 & 0.712 & 0.716 & 0.721 & 0.719 & 0.685 & 0.706 & $* * *$ \\
\hline Adults in household & 2.050 & 0.814 & 2.055 & 0.749 & 2.083 & 0.760 & 1.974 & 0.713 & $* * *$ \\
\hline Num. elderly in household & 0.097 & 0.330 & 0.054 & 0.240 & 0.054 & 0.242 & 0.052 & 0.233 & \\
\hline Num. Persons/bedroom & 1.875 & 0.972 & 2.145 & 1.085 & 2.007 & 0.988 & 2.545 & 1.242 & $* * *$ \\
\hline Rural & 0.311 & 0.463 & 0.322 & 0.467 & 0.310 & 0.462 & 0.356 & 0.479 & $* * *$ \\
\hline Poor household & 0.227 & 0.419 & 0.275 & 0.446 & 0.236 & 0.425 & 0.384 & 0.486 & $* * *$ \\
\hline Num. Persons in Household & 5.083 & 1.765 & 5.937 & 1.786 & 5.606 & 1.648 & 6.892 & 1.823 & $* * *$ \\
\hline Num. Obs. & \multicolumn{2}{|c|}{43752} & \multicolumn{2}{|c|}{16448} & \multicolumn{2}{|c|}{12217} & \multicolumn{2}{|c|}{4231} & \\
\hline
\end{tabular}

Source: Chile's CASEN surveys (1990, 1992, 1994, 1996, 1998, 2000, 2003, 2006 and 2009). Observed characteristics include woman's age, education of head of household, education of grandmother, age at first birth of grandmother, grandmother's age when woman was born, dummy variable for female head of household, number of teens in household (age 13-19), number of youth (age 20-24) in household, number of adults (age 25-59) in household, and number elderly (age 60+) in household, household density (persons per bedroom), dummy for rural location, and household poverty status. All differences across groups motherhood status are statistically significant. ${ }^{a}$ Mean test performed under the null hypotheis of equality of means between sisters that are mothers and sisters that are not mothers. ${ }^{* * * *} p<0.01,{ }^{* *} p<0.05$, and ${ }^{*} p<0.1$. ${ }^{b}$ Monthly adult income per capita includes income earned by household members aged 25 and older, divided by total household members, in 2009 Chilean pesos. Exchange rate 2009 : CLP560/US\$. 
Table 8. Effect of adolescent motherhood on education outcomes

\begin{tabular}{|c|c|c|c|c|c|c|c|c|c|}
\hline \multirow{3}{*}{ Outcome: } & \multicolumn{3}{|c|}{ Full sample } & \multicolumn{3}{|c|}{ Mothers } & \multicolumn{3}{|c|}{ Teen Mothers and non mothers } \\
\hline & $(1)$ & $(2)$ & (3) & (4) & (5) & $(6)$ & (7) & (8) & (9) \\
\hline & OLS & Matching & Sisters & OLS & Matching & Sisters & OLS & Matching & Sisters \\
\hline Obtained high school diploma & $\begin{array}{l}-0.2214^{* * *} \\
(0.007)\end{array}$ & $\begin{array}{l}-0.2234 * * * \\
(0.008)\end{array}$ & $\begin{array}{l}-0.1186 * * * \\
(0.020)\end{array}$ & $\begin{array}{l}-0.1614 * * * \\
(0.009)\end{array}$ & $\begin{array}{l}-0.1575^{* * *} \\
(0.012)\end{array}$ & $\begin{array}{l}-0.0930 * * \\
(0.041)\end{array}$ & $\begin{array}{l}-0.2382 * * * \\
(0.007)\end{array}$ & $\begin{array}{l}-0.2419 * * * \\
(0.008)\end{array}$ & $\begin{array}{l}-0.1263^{* * *} \\
(0.022)\end{array}$ \\
\hline Mean outcome & 0.704 & 0.705 & 0.679 & 0.532 & 0.533 & 0.509 & 0.715 & 0.716 & 0.689 \\
\hline Marginal effect (coefficient/mean) & $-31 \%$ & $-32 \%$ & $-17 \%$ & $-30 \%$ & $-30 \%$ & $-18 \%$ & $-33 \%$ & $-34 \%$ & $-18 \%$ \\
\hline Enrolled in post-secondary education & $\begin{array}{l}-0.1612 * * * \\
(0.005)\end{array}$ & $\begin{array}{l}-0.1574 * * * \\
(0.005)\end{array}$ & $\begin{array}{l}-0.0854 * * * \\
(0.015)\end{array}$ & $\begin{array}{l}-0.0494 * * * \\
(0.007)\end{array}$ & $\begin{array}{l}-0.0442 * * * \\
(0.007)\end{array}$ & $\begin{array}{l}-0.0161 \\
(0.024)\end{array}$ & $\begin{array}{l}-0.1880 * * * \\
(0.006)\end{array}$ & $\begin{array}{l}-0.1731^{* * *} \\
(0.006)\end{array}$ & $\begin{array}{l}-0.1058 * * * \\
(0.018)\end{array}$ \\
\hline Mean outcome & 0.331 & 0.330 & 0.305 & 0.131 & 0.131 & 0.115 & 0.355 & 0.355 & 0.328 \\
\hline Marginal effect (coefficient/mean) & $-49 \%$ & $-48 \%$ & $-28 \%$ & $-38 \%$ & $-34 \%$ & $-14 \%$ & $-53 \%$ & $-49 \%$ & $-32 \%$ \\
\hline Years of schooling & $\begin{array}{l}-1.0922 * * * \\
(0.036)\end{array}$ & $\begin{array}{l}-1.0980 * * * \\
(0.046)\end{array}$ & $\begin{array}{l}-0.4525^{* * *} \\
(0.117)\end{array}$ & $\begin{array}{l}-0.7316^{* * *} \\
(0.044)\end{array}$ & $\begin{array}{l}-0.7100 * * * \\
(0.065)\end{array}$ & $\begin{array}{l}-0.3472 \\
(0.217)\end{array}$ & $\begin{array}{l}-1.1927^{* * *} \\
(0.037)\end{array}$ & $\begin{array}{l}-1.1485^{* * *} \\
(0.050)\end{array}$ & $\begin{array}{l}-0.5102 * * * \\
(0.137)\end{array}$ \\
\hline Mean outcome & 11.8 & 11.8 & 11.6 & 10.6 & 10.6 & 10.5 & 11.9 & 11.9 & 11.7 \\
\hline Marginal effect (coefficient/mean) & $-9 \%$ & $-9 \%$ & $-4 \%$ & $-7 \%$ & $-7 \%$ & $-3 \%$ & $-10 \%$ & $-10 \%$ & $-4 \%$ \\
\hline $\begin{array}{l}\text { Number of observations } \\
\text { Treated observations }\end{array}$ & 41,516 & $\begin{array}{l}41,393 \\
5,871\end{array}$ & 16,428 & 11,271 & $\begin{array}{l}11,236 \\
5,858\end{array}$ & 4,228 & 36,127 & $\begin{array}{l}36,012 \\
5,869\end{array}$ & 14,388 \\
\hline
\end{tabular}

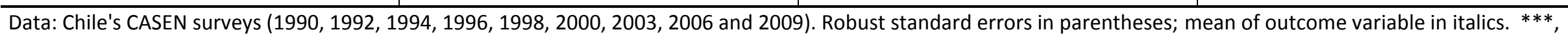
**, and * indicate statistical significance at the $1 \%, 5 \%$ and $10 \%$ levels, respectively.

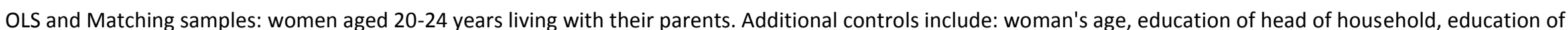

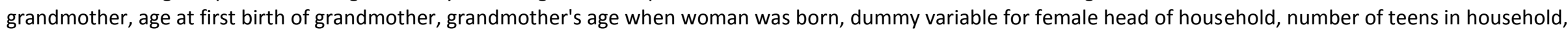
number of youth (age 20-24) in household, number of adults (age 25-59) in household, and number elderly (age 60+) in household, household density (persons per bedroom), dummy for rural location, woman's year of birth fixed-effects, municipality (comuna) fixed effects and full set of region-year controls. Sisters fixed effects

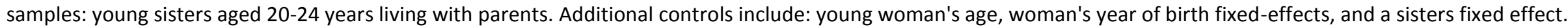


Table 9. Effects of adolescent motherhood on education outcomes, by poverty status

\begin{tabular}{|c|c|c|c|c|c|c|c|c|}
\hline \multirow{4}{*}{ Outcome: } & \multicolumn{4}{|c|}{ All women } & \multicolumn{4}{|c|}{ Mothers } \\
\hline & \multicolumn{2}{|c|}{ OLS } & \multicolumn{2}{|c|}{ Sisters } & \multicolumn{2}{|c|}{ OLS } & \multicolumn{2}{|c|}{ Sisters } \\
\hline & $(1)$ & $(2)$ & (3) & & $(5)$ & (6) & $(7)$ & (8) \\
\hline & Poor & Not poor & Poor & Not poor & Poor & Not poor & Poor & Not poor \\
\hline Obtained high school diploma & $\begin{array}{l}-0.2285^{* * *} \\
(0.012)\end{array}$ & $\begin{array}{l}-0.2055^{* * *} \\
(0.008)\end{array}$ & $\begin{array}{l}-0.1539 * * * \\
(0.033)\end{array}$ & $\begin{array}{l}-0.0958 * * * \\
(0.022)\end{array}$ & $\begin{array}{l}-0.1757^{* * *} \\
(0.017)\end{array}$ & $\begin{array}{l}-0.1486 * * * \\
(0.011)\end{array}$ & $\begin{array}{l}-0.1117^{*} \\
(0.060)\end{array}$ & $\begin{array}{l}-0.0535 \\
(0.050)\end{array}$ \\
\hline Mean & 0.495 & 0.766 & 0.478 & 0.755 & 0.374 & 0.610 & 0.359 & 0.602 \\
\hline Marginal effect (coefficient/mean) & $-46 \%$ & $-27 \%$ & $-32 \%$ & $-13 \%$ & $-47 \%$ & $-24 \%$ & $-31 \%$ & $-9 \%$ \\
\hline Enrolled in post-secondary education & $\begin{array}{l}-0.1002 * * * \\
(0.006)\end{array}$ & $\begin{array}{l}-0.1815^{* * *} \\
(0.007)\end{array}$ & $\begin{array}{l}-0.0696 * * * \\
(0.020)\end{array}$ & $\begin{array}{l}-0.0952 * * * \\
(0.021)\end{array}$ & $\begin{array}{l}-0.0216^{* * *} \\
(0.007)\end{array}$ & $\begin{array}{l}-0.0615^{* * *} \\
(0.009)\end{array}$ & $\begin{array}{l}0.016 \\
(0.031)\end{array}$ & $\begin{array}{l}-0.0385 \\
(0.035)\end{array}$ \\
\hline Mean & 0.135 & 0.388 & 0.129 & 0.372 & 0.047 & 0.172 & 0.041 & 0.160 \\
\hline Marginal effect (coefficient/mean) & $-74 \%$ & $-47 \%$ & $-54 \%$ & $-26 \%$ & $-46 \%$ & $-36 \%$ & $39 \%$ & $-24 \%$ \\
\hline Years of schooling & $\begin{array}{l}-1.0802^{* * *} \\
(0.069)\end{array}$ & $\begin{array}{l}-1.0217^{* * * *} \\
(0.041)\end{array}$ & $\begin{array}{l}-0.3219 \\
(0.212)\end{array}$ & $\begin{array}{l}-0.5453^{* * *} \\
(0.146)\end{array}$ & $\begin{array}{l}-0.8697^{* * * *} \\
(0.095)\end{array}$ & $\begin{array}{l}-0.6219 * * * \\
(0.051)\end{array}$ & $\begin{array}{l}-0.3038 \\
(0.290)\end{array}$ & $\begin{array}{l}-0.3837 \\
(0.293)\end{array}$ \\
\hline Mean & 10.3 & 12.2 & 10.2 & 12.1 & 9.6 & 11.1 & 9.5 & 11.1 \\
\hline Marginal effect (coefficient/mean) & $-11 \%$ & $-8 \%$ & $-3 \%$ & $-4 \%$ & $-9 \%$ & $-6 \%$ & $-3 \%$ & $-3 \%$ \\
\hline Number of observations & 9,422 & 32,094 & 3,497 & 8,996 & 3,696 & 7,575 & 1,453 & 2,401 \\
\hline
\end{tabular}

Data: Chile's CASEN surveys (1990, 1992, 1994, 1996, 1998, 2000, 2003, 2006 and 2009). Robust standard errors in parentheses; mean of outcome variable in italics. $* * *, * *$, and $*$ indicate statistical significance at the $1 \%, 5 \%$ and $10 \%$ levels, respectively.

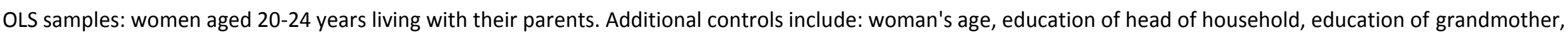

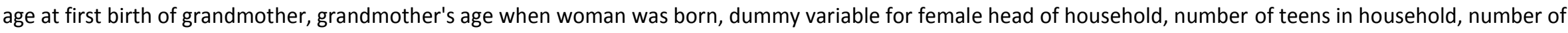
youth (age 20-24) in household, number of adults (age 25-59) in household, and number elderly (age 60+) in household, household density (persons per bedroom), dummy for rural location, woman's year of birth fixed-effects, municipality (comuna) fixed effects and full set of region-year controls. Sisters fixed effects samples: sisters aged 20-24 years living with parents. Additional controls include: woman's age, woman's year of birth fixed-effects, and a sisters fixed effect. 
Table 10. Effect of adolescent motherhood on education outcomes, by grandmother's education level (Low $=<12$ years of schooling; High $=12$ or more years of schooling)

\begin{tabular}{|c|c|c|c|c|c|c|c|c|}
\hline \multirow{4}{*}{ Outcome: } & \multicolumn{4}{|c|}{ All women } & \multicolumn{4}{|c|}{ Mothers } \\
\hline & \multicolumn{2}{|c|}{ OLS } & \multicolumn{2}{|c|}{ Sisters } & \multicolumn{2}{|c|}{ OLS } & \multicolumn{2}{|c|}{ Sisters } \\
\hline & $(1)$ & $(2)$ & (3) & (4) & (5) & (6) & (7) & (8) \\
\hline & Low & High & Low & High & Low & High & Low & High \\
\hline Obtained high school diploma & $\begin{array}{l}-0.2362^{* * *} \\
(0.007)\end{array}$ & $\begin{array}{l}-0.1329 * * * \\
(0.016)\end{array}$ & $\begin{array}{l}-0.1298 * * * \\
(0.022)\end{array}$ & $\begin{array}{l}-0.0594 \\
(0.038)\end{array}$ & $\begin{array}{l}-0.1669 * * * \\
(0.010)\end{array}$ & $\begin{array}{l}-0.1229 * * * \\
(0.020)\end{array}$ & $\begin{array}{l}-0.1151^{* *} \\
(0.045)\end{array}$ & $\begin{array}{l}0.1004 \\
(0.074)\end{array}$ \\
\hline Mean & 0.630 & 0.934 & 0.603 & 0.927 & 0.476 & 0.851 & 0.451 & 0.853 \\
\hline Marginal effect (coefficient/mean) & $-37 \%$ & $-14 \%$ & $-22 \%$ & $-6 \%$ & $-35 \%$ & $-14 \%$ & $-26 \%$ & $12 \%$ \\
\hline $\begin{array}{l}\text { Enrolled in post-secondary } \\
\text { education }\end{array}$ & $\begin{array}{l}-0.1424 * * * \\
(0.005)\end{array}$ & $\begin{array}{l}-0.2615^{* * *} \\
(0.019)\end{array}$ & $\begin{array}{l}-0.0721 * * * \\
(0.015)\end{array}$ & $\begin{array}{l}-0.1774^{* * *} \\
(0.052)\end{array}$ & $\begin{array}{l}-0.0436 * * * \\
(0.006)\end{array}$ & $\begin{array}{l}-0.1051 * * * \\
(0.027)\end{array}$ & $\begin{array}{l}-0.0133 \\
(0.023)\end{array}$ & $\begin{array}{l}-0.0115 \\
(0.142)\end{array}$ \\
\hline Mean & 0.217 & 0.683 & 0.190 & 0.683 & 0.084 & 0.402 & 0.065 & 0.406 \\
\hline Marginal effect (coefficient/mean) & $-66 \%$ & $-38 \%$ & $-38 \%$ & $-26 \%$ & $-52 \%$ & $-26 \%$ & $-20 \%$ & $-3 \%$ \\
\hline Years of schooling & $\begin{array}{l}-1.0969 * * * \\
(0.038)\end{array}$ & $\begin{array}{l}-1.0386 * * * \\
(0.083)\end{array}$ & $\begin{array}{l}-0.4488 * * * \\
(0.127)\end{array}$ & $\begin{array}{l}-0.4874 * \\
(0.261)\end{array}$ & $\begin{array}{l}-0.7567 * * * \\
(0.049)\end{array}$ & $\begin{array}{l}-0.5929 * * * \\
(0.105)\end{array}$ & $\begin{array}{l}-0.4419 * \\
(0.228)\end{array}$ & $\begin{array}{l}0.5294 \\
(0.508)\end{array}$ \\
\hline Mean & 11.1 & 13.8 & 11.0 & 13.8 & 10.2 & 12.7 & 10.1 & 12.7 \\
\hline Marginal effect (coefficient/mean) & $-10 \%$ & $-8 \%$ & $-4 \%$ & $-4 \%$ & $-7 \%$ & $-5 \%$ & $-4 \%$ & $4 \%$ \\
\hline Number of observations & 31,381 & 10,135 & 12,582 & 3,846 & 9,578 & 1,693 & 3,615 & 613 \\
\hline
\end{tabular}

Data: Chile's CASEN surveys (1990, 1992, 1994, 1996, 1998, 2000, 2003, 2006 and 2009). Robust standard errors in parentheses; mean of outcome variable in italics. $* * *, * *$, and $*$ indicate statistical significance at the $1 \%, 5 \%$ and $10 \%$ levels, respectively.

OLS samples: women aged 20-24 years living with their parents. Additional controls include: woman's age, education of head of household, education of grandmother, age at first birth of grandmother, grandmother's age when woman was born, dummy variable for female head of household, number of teens in household, number of youth (age 20-24) in household, number of adults (age 25-59) in household, and number elderly (age 60+) in household, household density (persons per bedroom), dummy for rural location, woman's year of birth fixed-effects, municipality (comuna) fixed effects and full set of region-year controls. Sisters fixed effects samples: sisters aged 20-24 years living with parents. Additional controls include: woman's age, woman's year of birth fixedeffects, and a sisters fixed effect. 


\section{Appendix A: Matching estimates}

Table A1: Logit model for prediction of teen motherhood

\begin{tabular}{|c|c|c|}
\hline \multirow{2}{*}{$\begin{array}{l}\text { Variables } \\
\text { Age }\end{array}$} & \multicolumn{2}{|c|}{ Teen Mother } \\
\hline & \multicolumn{2}{|l|}{-0.0095} \\
\hline & \multicolumn{2}{|l|}{0.013} \\
\hline \multirow[t]{2}{*}{ Education-Head of Hhold. (years) } & -0.034 & $* * *$ \\
\hline & \multicolumn{2}{|l|}{0.006} \\
\hline \multirow{2}{*}{ Education-Grandmother (years) } & -0.0396 & $* * *$ \\
\hline & \multicolumn{2}{|l|}{0.006} \\
\hline \multirow[t]{2}{*}{ Grandmother's age at first birth (years) } & -0.0206 & $* * *$ \\
\hline & \multicolumn{2}{|l|}{0.006} \\
\hline \multirow{2}{*}{ Grandmother's age at woman's birth (years) } & \multicolumn{2}{|l|}{0.0092} \\
\hline & \multicolumn{2}{|l|}{0.006} \\
\hline \multirow[t]{2}{*}{ Female-headed hhold. } & & $*$ \\
\hline & \multicolumn{2}{|c|}{0.045} \\
\hline \multirow[t]{2}{*}{ Log adult income per capita } & -0.0436 & $* * *$ \\
\hline & \multicolumn{2}{|l|}{0.005} \\
\hline \multirow[t]{2}{*}{ Num. teenagers in household } & -0.2544 & $* * *$ \\
\hline & \multicolumn{2}{|l|}{0.021} \\
\hline \multirow[t]{2}{*}{ Num. young adults in household } & -0.2748 & $* * *$ \\
\hline & \multicolumn{2}{|l|}{0.026} \\
\hline \multirow[t]{2}{*}{ Num. adults in household } & -0.2965 & $* * *$ \\
\hline & \multicolumn{2}{|c|}{0.034} \\
\hline \multirow[t]{2}{*}{ Num. elderly in household } & -0.2419 & $* * *$ \\
\hline & \multicolumn{2}{|l|}{0.063} \\
\hline \multirow[t]{2}{*}{ Num. Persons/bedroom } & 0.4698 & $* * *$ \\
\hline & \multicolumn{2}{|c|}{0.015} \\
\hline \multirow[t]{2}{*}{ Rural } & -0.0869 & $* *$ \\
\hline & \multicolumn{2}{|l|}{0.041} \\
\hline \multirow[t]{2}{*}{ Constant } & \multicolumn{2}{|l|}{0.3859} \\
\hline & 0.426 & \\
\hline Observations & 41,393 & \\
\hline Log likelihood & -15380.4 & \\
\hline Comuna Fixed Effects & Yes & \\
\hline Number of Comunas & 319 & \\
\hline
\end{tabular}

Data: Chile's CASEN surveys (1990, 1992, 1994, 1996, 1998, 2000, 2003, 2006 and 2009). Robust standard errors in parentheses; mean of outcome variable in italics. $* * *, * *$, and $*$ indicate statistical significance at the $1 \%, 5 \%$ and $10 \%$ levels, respectively. Additional controls include: woman's year of birth fixed-effects, municipality fixed effects and full set of region-year controls. 
Table A2: Covariate balancing and absolute bias reduction for matching estimates

\begin{tabular}{l|rr|c|c}
\hline \multirow{2}{*}{ Variable } & \multicolumn{2}{|c|}{ Mean } & \% Reduction & \multirow{2}{*}{\begin{tabular}{c} 
t-test \\
\cline { 2 - 3 }
\end{tabular}} \\
\cline { 2 - 3 } Age & $\begin{array}{c}\text { Teen } \\
\text { Mother }\end{array}$ & $\begin{array}{c}\text { Not Teen } \\
\text { Mother }\end{array}$ & Absolute bias & \\
Education-Head of Hhold. (years) & 21.7510 & 21.7460 & 87.5 & 0.20 \\
Education-Grandmother (years) & 6.5646 & 6.4426 & 91.1 & $1.67 *$ \\
Grandmother's age at first birth (years) & 6.4595 & 6.3678 & 93.0 & 1.29 \\
Grandmother's age at woman's birth & 24.6400 & 24.6130 & 89.7 & 0.22 \\
(years) & 26.7390 & 26.6750 & 79.3 & 0.48 \\
Female-headed hhold. & 0.2914 & 0.2931 & 97.6 & -0.20 \\
Log adult income per capita & 9.7419 & 9.7249 & 97.6 & 0.29 \\
Num. teenagers in household & 0.6512 & 0.6454 & 69.9 & 0.38 \\
Num. young adults in household & 0.3761 & 0.3733 & 94.1 & 0.25 \\
Num. adults in household & 1.9871 & 1.9767 & 90.4 & 0.73 \\
Num. elderly in household & 0.0979 & 0.1017 & 28.4 & -0.60 \\
Num. Persons/bedroom & 2.3055 & 2.2563 & 90.0 & $2.13 * *$ \\
Rural & 0.3378 & 0.3396 & 94.3 & -0.21 \\
\hline
\end{tabular}

Notes: Additional controls include: woman's year of birth fixed-effects, municipality fixed effects and full set of region-year controls. All variables not reported are balanced between treatment groups. t-tests for equality of means in the treated and non-treated groups, with ${ }^{* * *} p<0.01,{ }^{* *} p<0.05$, and ${ }^{*} p<0.1$. 